\title{
Vitamin C pretreatment protects from nickel-induced acute nephrotoxicity in mice
}

\author{
Imed-Eddine Kadi and Faouzi Dahdouh \\ Department of Biochemistry and Microbiology, Faculty of Sciences, \\ Mohamed Boudiaf M'Sila University, Algeria
}

[Received in December 2015; CrossChecked in December 2015; Accepted in July 2016]

\begin{abstract}
Nickel is an abundant carcinogenic and nephrotoxic metal whose activity leads to renal impairment. Previous studies have shown a protective effect of simultaneous vitamin $\mathrm{C}$ administration on acute and chronic nickel toxicity. However, very little research relating to the effect of vitamin $\mathrm{C}$ pretreatment in preventing nickel-induced acute nephrotoxicity is available. Therefore, the present study aimed to determine the efficiency of vitamin C (VC) pretreatment in preventing acute renal toxicity of nickel. Mice were pretreated orally with vitamin $\mathrm{C}\left(16.6 \mathrm{mg} \mathrm{kg}^{-1}\right.$ body weight, b.w.) for seven consecutive days, prior to intraperitoneal (i.p.) administration of nickel chloride at different doses $\left(3,5\right.$, and $10 \mathrm{mg} \mathrm{Ni} \mathrm{kg}^{-1}$ b.w.) for an exposure period of 24 hours. Thereafter, animals were killed and kidney tissue and blood samples were taken for histological examination and biochemical marker analyses. Vitamin C pretreatment alone did not alter the levels of serum kidney markers (creatinine, urea, and uric acid). However, treatment with $\mathrm{Ni}$ alone showed a significant increase in the levels of serum creatinine, urea, and uric acid with marked necrotic epithelial cells and infiltration by inflammatory cells in kidney sections as compared to the control group. Pretreatment with vitamin $\mathrm{C}$ and treatment with $\mathrm{Ni}$ at all doses tested for 24 hours showed a significant decrease in the levels of serum creatinine, urea, and uric acid, as well as an improvement in histological changes compared to those previously seen in the group treated with $\mathrm{Ni}$ alone. It is concluded that vitamin $\mathrm{C}$ pretreatment effectively improved renal function and tissue damage caused by nickel.
\end{abstract}

KEY WORDS: creatinine; histopathology; kidney dysfunction; urea; uric acid

Nickel is a ubiquitous environmental pollutant used extensively in industry for various commercial processes including: production of steel, metal alloys, batteries, coins, magnets, paints, and medical implants $(1,2)$. Humans are exposed to nickel by ingesting contaminated foodstuffs or inhaling cigarette smoke (3). Nickel is transported by blood and is retained by various tissues or excreted, mainly through urine, making thus the kidney the target organ of nickel toxicity and carcinogenicity (4-8). Several reports have evidenced that nickel is able to cause harmful effects to human and animal health, which increase organ cancer and injury risk $(9,10)$. Nickel is a well-known cytotoxic metal that may affect various cell lines including kidney cells. It may generate reactive oxygen species, which leads to lipid peroxidation and oxidation of DNA and proteins and results in cell apoptosis and nephrotoxicity $(11,12)$. Recently, antioxidant supplements have received much attention due to their antioxidant activity and a free radicalscavenging ability to quench reactive oxygen species (ROS) that induce oxidative tissue injuries and cellular damage (13). Vitamin C (ascorbic acid or ascorbate) is a natural substance abundant in fresh fruits and vegetables (14). It is also a powerful water-soluble antioxidant and a free radical

Correspondence to: Faouzi Dahdouh, Department of Biochemistry and Microbiology, Faculty of Sciences, Mohamed Boudiaf M'Sila University, 28000, Algeria. E-mail:faouzidahdouh@ymail.com scavenger that acts as a reducing agent, donating electrons to ROS free radicals, making these more stable and less reactive (15). Additionally, vitamin $\mathrm{C}$ contributes to the restoration of depleted vitamin $\mathrm{E}$ and intracellular glutathione levels. This helps to actively fight oxidative stress-mediated cellular damage that leads to cell death (16). An in vitro study (17) showed that nickel-induced oxidative stress, mediated via an increased expression of JMJD1A and the related hypoxia-response genes GLUT1 and HIF-1 $\alpha$ in human embryonic kidney cells, was greatly reversed by ascorbate. In experimental animals, simultaneous administration of vitamin $\mathrm{C}$ with nickel reduced oxidative damage to the biological system by boosting the antioxidant protective system to prevent lipid peroxidation and oxidative stress in the liver (18) and the lung (19). Furthermore, vitamin $\mathrm{C}$ at a single $\left(250 \mathrm{mg} \mathrm{kg}^{-1}\right.$ b.w.) and multiple doses $\left(500 \mathrm{mg} \mathrm{kg}^{-1}\right.$ b.w.) administered to mice one hour prior to cisplatin i.p. injection showed an improvement of the antioxidant status of cells, functional markers and kidney histopathological changes (20). Similarly, KarabulutBulanet al. (21) have demonstrated that vitamin $\mathrm{C}$ given to rats (250 mg kg-1 a day) one hour prior to cadmium administration consecutively over eight days attenuated cadmium-induced kidney oxidative injury. It was also reported that vitamin $\mathrm{C}$ pretreatment protected against long-term exposure to lead-induced histopathological 
changes in the kidney of rats (22). To our knowledge, there is no data showing the protective effect of vitamin $\mathrm{C}$ pretreatment in preventing renal impairment following exposure to different doses of nickel. Therefore, the current study was designed to investigate the beneficial effect of vitamin $\mathrm{C}$ pretreatment against $\mathrm{Ni}$-induced nephrotoxicity in male mice.

\section{MATERIALS AND METHODS}

\section{Animals}

Forty-eight male Swiss albino mice with a mean of $27.31 \pm 0.17 \mathrm{~g}$ (Animal Unit of "Pasteur" Institute of Algiers, Algeria) were used in this study. The animals were cared for in compliance with the guidelines of the Institutional Animal Ethical Committee Research (AFRO. No 478, 2009), as approved by the Faculty of Sciences at Annaba University, and the study was conducted in accordance with the "Guide for the Care and Use of Laboratory Animals". Mice were acclimatised to our laboratory conditions for two weeks and were thereafter weighted and divided into six equal groups. Normal mice chow (Oneb, Béjaïa, Algeria) and water were provided ad libitum throughout the period of the study.

\section{Chemicals}

$\mathrm{Ni}$ as nickel chloride, $\mathrm{NiCl}_{2}$, and vitamin $\mathrm{C}$ (L-ascorbic acid: $\mathrm{C}_{6} \mathrm{H}_{8} \mathrm{O}_{6}$ ) and all other chemicals used in the experiment were purchased from Sigma Chemical Inc. (St. Louis, MO, USA).

\section{Experimental procedure}

The acclimatised animals were weighted and randomly divided into six experimental groups of six animals each. Group I (control group): mice had free access to standard diet and water ad libitum. Group II (VC): mice were treated orally with vitamin $\mathrm{C}$ at a dose of $16.6 \mathrm{~g} \mathrm{~kg}^{-1}$ of b.w. for seven consecutive days. Groups III (Ni3), IV (Ni5), and V (Ni10): $\mathrm{NiCl}_{2}$ was injected i.p. at doses of 3, 5, and 10 $\mathrm{mg}$ Ni per kg of b.w., respectively. Animals in these groups were killed $24 \mathrm{~h}$ after Ni injection. Groups VI (Ni3+VC), VII (Ni5+VC), and VIII (Ni10+VC): mice were pretreated with vitamin $\mathrm{C}$ for seven consecutive days. On day 8 , the animals received i.p. 3, 5, and $10 \mathrm{mg}$ of $\mathrm{Ni}$ per $\mathrm{kg}$ b.w., respectively, over $24 \mathrm{~h}$. Animals were killed after being anaesthetised with chloroform. Blood was collected into lithium heparin blood tubes and placed immediately into an ice bath until centrifugation at 3,000 $\mathrm{g}$ for $10 \mathrm{~min}$ at $+4^{\circ} \mathrm{C}$ (Hettich Mikro 185 microliter centrifuge).

Serum samples were extracted and analysed for nephritic markers (creatinine, urea, and uric acid). The kidney was removed and processed immediately for histological examination.
Vitamin $\mathrm{C}$ and nickel chloride doses were chosen according to the protocol established by Dhir et al. (23) and Chen et al. (24), respectively.

\section{Determination of nickel concentration}

The concentration of $\mathrm{Ni}$ in renal tissue was determined as previously described (25). Briefly, $1 \mathrm{~g}$ of fresh tissue was homogenised in cold $\mathrm{KCl}$ using a tissue homogeniser (SCILOGEX D160). Then, the homogenate was added to $3 \mathrm{ml}$ of mixed acid solution $\left(\mathrm{HClO}_{4} / \mathrm{HNO}_{3}, 1: 3\right.$, v/v). After that, the samples were digested using microwave heating, and Ni concentration was determined using a Perkin-Elmer model 5100 PC Flame Atomic Absorption Spectrophotomer (FAAS).

\section{Biochemical assays}

Serum biochemical markers: creatinine, urea, and uric acid were measured as functional markers for nephrotoxicity. They were assessed using commercially available diagnostic kits (Spinreact, Spain, ref: Creatinine-1001111, urea-1001329, and uric acid-1001011), according to the enzymatic colorimetric method and using a spectrophotometer (Jenway 6505, Jenway LTD, UK).

\section{Histopathological evaluation}

Removed kidney samples were fixed for $48 \mathrm{~h}$ in $10 \%$ formalin-saline (5-6 $\mu \mathrm{m}$ thick) and dehydrated by passing successfully in different mixtures of ethyl alcohol-water, cleaned in xylene, and embedded in paraffin. Sections of the tissue (5-6 $\mu \mathrm{m}$ thick) were prepared using a rotary microtome and were stained with haematoxylin and eosin (H\&E) dye, which was mounted in a neutral deparaffinated xylene medium for microscopic examinations. Microscopic images were taken by a digital camera (Leica MC190-HD, Germany) mounted on a Leica DM-1000 microscope with $40 \times$ of objective lens.

\section{Statistical analysis}

Data were analysed using the GraphpadPrism statistical program (software version 6.0). All results are given as means \pm SE. Comparison between group means of each parameter separately was tested by one-way ANOVA repeated measures, followed by the Protected Least Significant Difference Fisher's test (PLSD Fisher) and the level of significance was set at $p<0.05$.

\section{RESULTS}

\section{Clinical signs of toxicity}

At the end of the experiment, vitamin $\mathrm{C}$ treated mice were healthy and their behavioural patterns were comparable to controls. However, in the nickel treated groups, several 
clinical signs such as reduced activity, weakness, and reduced food and water intake were observed within $24 \mathrm{~h}$ of Ni injection. These clinical signs were almost absent in animals pretreated with vitamin $\mathrm{C}$ followed by $\mathrm{Ni}$ injection.

\section{Ni concentration in the kidney}

As seen in Figure 1, exposure to nickel at various doses (3, 5, and $10 \mathrm{mg} \mathrm{kg}^{-1}$ b.w.) significantly increased its concentration in the kidney as compared to that seen in control mice (respectively, $p<0.01, p<0.001, p<0.001$ ). But when nickel and vitamin $\mathrm{C}$ pretreated and nickel only groups were compared, a significant decrease $(p<0.001 \mathrm{Ni3}$ $p<0.01 \mathrm{Ni5}$ and $\mathrm{Ni10}$ ) of $\mathrm{Ni}$ level in the kidney was observed.

\section{Concentration of Nickel in kidney}

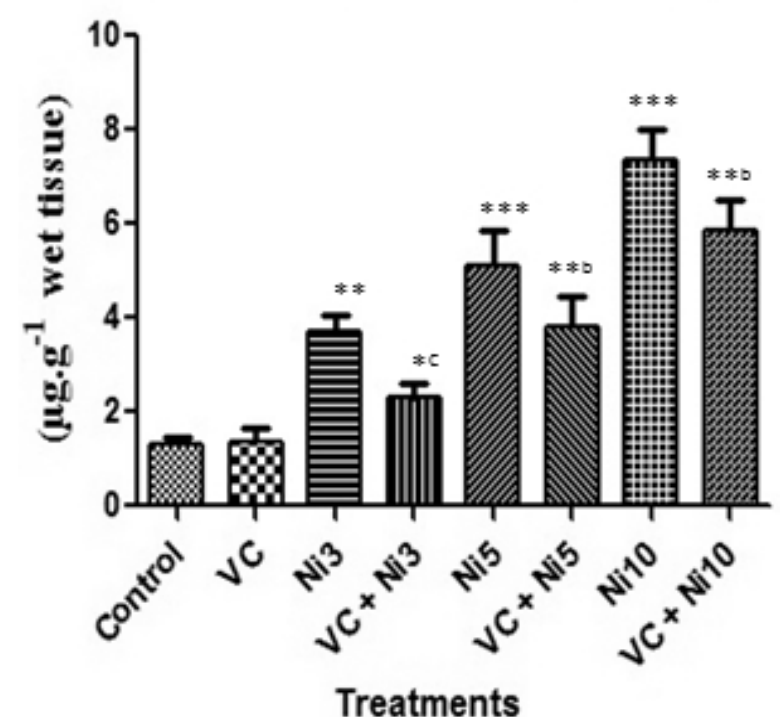

Figure1 Vitamin C pretreatment reduced tissue Ni concentration in the kidney, after $24 \mathrm{~h}$ of i.p. administration of $\mathrm{NiCl}_{2}$

\section{Effect of treatments on functional kidney markers}

Treatment of mice with 3,5 , and $10 \mathrm{mg} \mathrm{kg}^{-1}$ b.w. of nickel chloride for 24 hours caused a significant increase $(p<0.01)$ in the levels of serum nephritic markers (urea, uric acid and creatinine) when compared with control group. Similarly, vitamin C pretreatment prior to $\mathrm{Ni}$ administration showed a significant increase $(p<0.05)$ in the above mentioned parameters when compared with those seen in controls. But when compared with Ni3, Ni5, and Ni10 treated groups, a significant decrease (respectively, $p<0.05$; $p<0.01 ; p<0.001$ ) was noticed (Fig. 2).

\section{Kidney histopathological changes}

H\&E kidney stained sections showed a normal structure of the renal cortex and medulla of control mice and the mice treated with vitamin $\mathrm{C}$ alone (Fig. 3A and B). Ni treatment resulted in kidney histopathological changes as indicated by tubular degeneration and necrosis and infiltration by
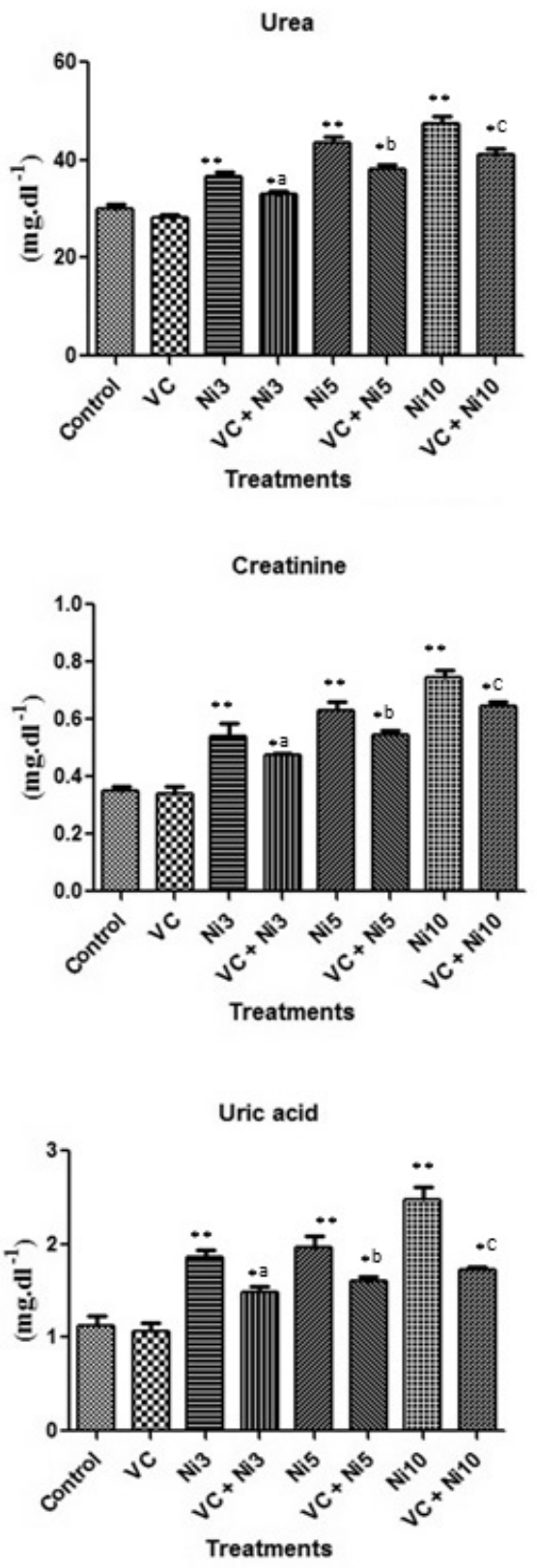

Figure2 Vitamin $C$ pretreatment improves kidney functional markers upon Ni toxicity.

Results are mean \pm S.E. One-way ANOVA and Protected Least Significant Difference Fisher's test. ( $n=6$ for all groups). ${ }^{*} \mathrm{p}<0.05$, ${ }^{* * \mathrm{p}}<0.01,{ }^{* * *} \mathrm{p}<0.001: V C ; \mathrm{N3} ; \mathrm{VC}+\mathrm{Ni3} ; \mathrm{Ni5} ; \mathrm{VC}+\mathrm{Ni5} ; \mathrm{Ni10}$; $V C+N i 10$ versus Control. ${ }^{a} \mathrm{p}<0.05,{ }^{b} \mathrm{p}<0.01,{ }^{C} \mathrm{p}<0.001: V C+N i 3$ versus $\mathrm{Ni3}$; $\mathrm{VC}+\mathrm{Ni} 5$ versus $\mathrm{Ni} 5$; $\mathrm{VC}+\mathrm{Ni10}$ versus Ni10

inflammatory cells (fig. 3C, D, and E). The severity of tissue alterations increased commensurate to the increase in nickel doses. On the contrary, kidney histology was somewhat dependently regained in the combined treatments following the decrease in Ni doses (Fig. 4F, G, and H).

\section{DISCUSSION}

The study provides evidence that pretreatment of mice with vitamin $\mathrm{C}$ is nephroprotective against acute toxicity 

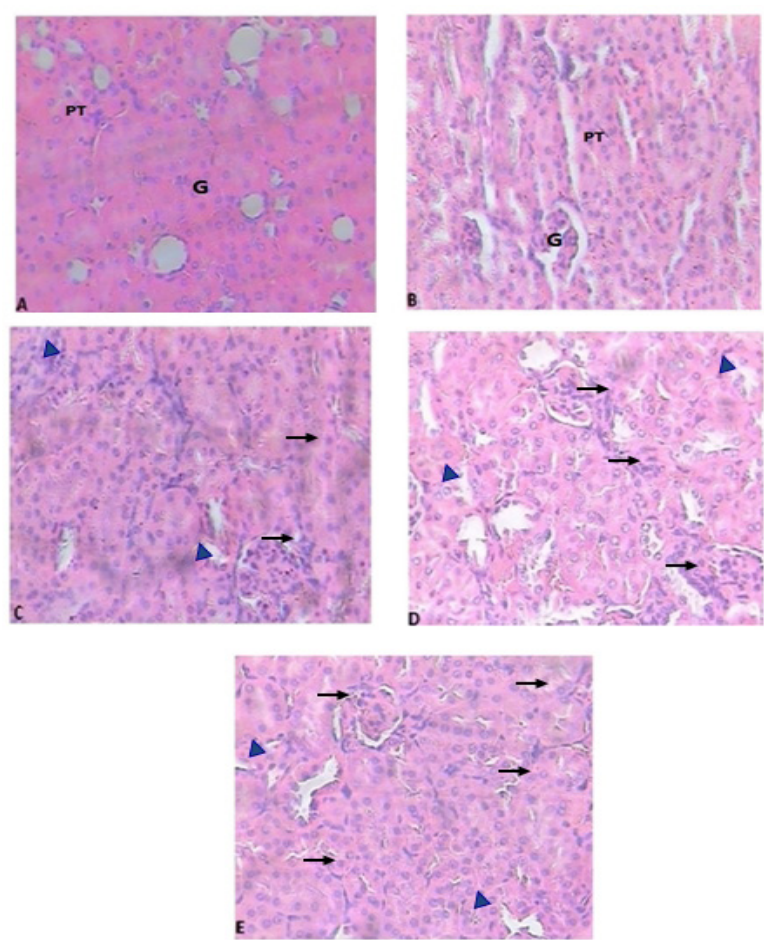

Figure 3 Hematoxylin and eosin-stained sections of the kidneys from control mice $(\boldsymbol{A})$, vitamin $C$ treatment $(\boldsymbol{B})$ and Ni treated mice: $3 \mathrm{mg} \mathrm{Ni} \mathrm{kg-1}^{-1}$ b.w. (C); $5 \mathrm{mg} \mathrm{Ni} \mathrm{kg-1}^{-1}$ b.w.(D); and $10 \mathrm{mg} \mathrm{Ni} \mathrm{kg}^{-1}$ b.w. (E) (x400).

(A) and (B) Kidney sections from control mice and those that received vitamin C alone by oral gavage in a dose of $16.6 \mathrm{mg} \mathrm{kg}^{-1}$ b.w. for seven consecutive days show a normal structure of glomeruli ' $\mathbf{G}$ " and medulla, with no proximal tubular 'PT", necrosis.

(C), (D), and (E) Kidney sections from mice that received 3, 5, and $10 \mathrm{mg} \mathrm{kg}^{-1}$ b.w., i.p., of $\mathrm{Ni}$ and that were killed at $24 \mathrm{~h}$ after Ni injection show up to $40 \%, 60 \%$, and $80 \%$, respectively, the presence of renal tubular degeneration and necrosis (black arrow) and infiltration by inflammatory cells (blue arrow head)

of nickel at all tested doses (3, 5, and $10 \mathrm{mg} \mathrm{kg}^{-1}$ b.w.) through a substantial decrease in the concentration of serum urea, uric acid, and creatinine and the concentration of $\mathrm{Ni}$ in renal tissue. Furthermore, the expressed histologic damage scores were lower, showing minimal tubular generation, necrosis, and infiltration by inflammatory cells that were induced by nickel treatment.The nephrotoxic effect of $\mathrm{Ni}$ is observed in a significant increase in the serum level of urea and creatinine, which may result in a decrease in reabsorption at renal epithelium and disruption of glomerular filtration rate. This increases the risk of renal failure (26). The measurements of creatinine, urea, and uric acid are considered a tool in the clinical diagnosis of renal dysfunction following acute and chronic oxidative kidney injury $(27,28)$. The increased level of $\mathrm{Ni}$ in the kidney that was observed after Ni treatment could be explained by high affinity of metallothionein, a metal binding protein for $\mathrm{Ni}$ (29). The adverse effects of $\mathrm{Ni}$ on kidney function are potentially related to oxidative stress and overproduction of free radicals that can cause oxidation of biomolecules (lipids, proteins, DNA), eventually leading to renal cell death (30). Vitamin C pretreatment prior to Ni administration reversed kidney function by normalising the increased renal parameters and histopathological changes, as well as by reducing $\mathrm{Ni}$ accumulation in the kidney compared to mice that received $\mathrm{Ni}$ alone. This is in line with what was previously reported on the simultaneous administration of vitamin $\mathrm{C}$ supplementation to rodents against nickelinduced renal oxidative damage $(31,32)$. In parallel, oral administration of a single dose of vitamin C (150$350 \mathrm{mg} \mathrm{kg}^{-1}$ b.w, i.p.) to rats, six hours prior to acute administration of cisplatin (6 $\mathrm{mg} \mathrm{kg}^{-1}$ b.w., i.p.), for four consecutive days showed remarkable protection against kidney damage induced by cisplatin (33). Also, Shaban El-Neweshy and Said El-Sayed (22) have investigated the nephroprotective effect of vitamin $\mathrm{C}\left(20 \mathrm{mg} \mathrm{kg}^{-1} \mathrm{~b}\right.$.w., oral route) pretreatment against renal histopathological changes following oral administration of lead to rats, 30 min after vitamin $\mathrm{C}$ administration.

These results suggested that vitamin $\mathrm{C}$ could strongly enhance the cellular antioxidant capacity to counteract ROS-mediated free radical reactions before they reached their cellular targets. As reported, vitamin $\mathrm{C}$ reduces the absorption of dietary nickel in intestine (34), suggesting
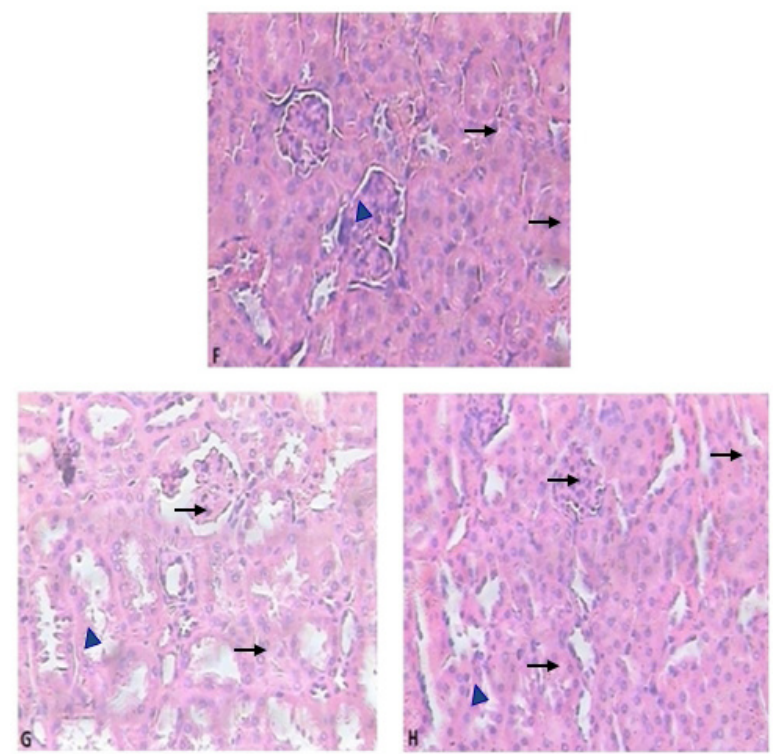

Figure 4 Hematoxylin and eosin-stained sections of mice kidney after combined treatments $(\mathrm{Ni}+\mathrm{VC})(x 400)$.

$(\mathbf{F}),(\mathbf{G})$, and $\mathbf{( H )}$ Kidney sections from the mice pretreated with a single dose (16.6 $\mathrm{mg} \mathrm{kg}^{-1}$ b.w.) of vitamin $C$ for seven consecutive days prior to the injection, i.p., of 3, 5, and $10 \mathrm{mg} \mathrm{kg}^{-1}$ b.w. of $\mathrm{Ni}$ and killed $24 \mathrm{~h}$ after Ni treatment show mild tubular degeneration and necrosis with presence of some inflammatory cells.

Treatment groups $\boldsymbol{V C}$ : Mice received vitamin $C$ by oral gavage in a dose of $16.6 \mathrm{mg} \mathrm{kg}^{-1}$ b.w.per day for seven consecutive days. $\mathrm{Ni3}$, Ni5, and Ni10: $\mathrm{NiCl}_{2}$ was injected intraperitoneally at doses of 3,5 , and $10 \mathrm{mg} \mathrm{kg}^{-1} \mathrm{~b}$.w. respectively, and the mice were killed 24 h after Ni injection. $\mathbf{V C}+\mathrm{Ni3}, \mathbf{V C}+\mathrm{Ni5}$ and $\mathbf{V C}+\mathrm{Ni10}$ : Mice were pretreated with vitamin $C\left(16.6 \mathrm{mg} \mathrm{kg}^{-1} \mathrm{~b} . \mathrm{w}\right.$.) for seven consecutive days. On day $8, \mathrm{Ni}$ was injected intraperitoneally at 3,5 , and $10 \mathrm{mg} \mathrm{kg}^{-1}$ respectively, and the animals were killed $24 \mathrm{~h}$ after Ni injection 
that vitamin $\mathrm{C}$ may act as a chelating agent of nickel leading to a lower cellular uptake of nickel, protecting consequently against kidney oxidative injury.

In conclusion, pretreatment with vitamin $\mathrm{C}$ effectively ameliorated kidney dysfunction by decreasing the serum functional kidney markers (urea, creatinine, and uric acid) and the concentration of $\mathrm{Ni}$ in the kidney of mice caused by acute administration of various doses $\left(3,5\right.$, and $\left.10 \mathrm{mg} \mathrm{kg}^{-1}\right)$ of nickel. Thus, administration of vitamin $\mathrm{C}$ prior to nickel treatment provides an efficient protection against $\mathrm{Ni}$ induced acute nephrotoxicity in mice. Further studies need to ascertain the protective effect of pretreatment with more doses of vitamin $\mathrm{C}$ against $\mathrm{Ni}$-induced kidney oxidative stress, and therefore these should focus on the nephroprotective effect of vitamin $\mathrm{C}$ in a dose dependent manner.

\section{Acknowledgements}

The authors would like to thank Dr. Boudjellal Amel and Mr. Benkhaled Abedarahimof Mohamed Boudiaf, M'Sila University for their technical assistance.

\section{Conflict of interest}

All authors have declared that no competing interests exist.

\section{REFERENCES}

1. De Brouwere K, Buekers J, Cornelis C, Schlekat CE, Oller AR. Assessment of indirect human exposure to environmental sources of nickel: oral exposure and risk characterization for systemic effects. Sci Total Environ 2011;419:25-36. doi: 10.1016/j.scitotenv.2011.12.049

2. Feilzer AJ, Kleverlaan CJ, Prahl C, Muris J. Systemischereacties op in de mondtoegepastemetaallegeringen [Systemic reactions to orally applied metal alloys, in Dutch]. Ned TijdschrTandheelkd 2013;120:335-41. doi: 10.5177/ ntvt.2013.06.13126

3. Edelman DA, Rogglit VL. The accumulation of nickel in human lungs. Environ Health Perspect 1989;81:221-4. PMID: 2759060

4. Severa J, Vyskocil A, Fiala Z, Cizkova M. Distribution of nickel in body fluids and organs of rats chronically exposed to nickel sulphate. Hum ExpToxicol 1995;14:955-8. doi: 10.1177/096032719501401204

5. Sarkar B. Nickel in blood and kidney. In: Brown SS, Sunderman FW Jr, editors. Nickel toxicology. New York (NY): Academic Press; 1980. p. 81-4.

6. Arena VC, Sussman NB, Redmond CK, Costantino JP, Trauth $\mathrm{JM}$. Using alternative comparison populations to assess occupation-related mortality risk results for the high nickel alloys workers cohort. J Occup Environ Med 1998;40:907-16. PMID: 9800177

7. Sunderman FW Jr, Maenza RM, Hopfer SM, Mitchell JM, Allpass PR, Damjanov I. Induction of renal cancers in rats by intrarenal injection of nickel subsulfide. J Environ Pathol Toxicol 1979;2:1511-27. PMID: 528855
8. Minigaliyeva IA, Katsnelson BA, Privalova LI, Gurvich VB, Panov VG, Varaksin AN, Makeyev OH, Sutunkova MP, Loginova NV, Kireyeva EP, Grigoryeva EV, Slyshkina TV, Ganebnykh EV, Grebenkina SV. Toxicodynamic and toxicokinetic descriptors of combined chromium (VI) and nickel toxicity.Int J Toxicol 2014;33:498-505. doi: 10.1177/1091581814555915

9. Heim HE, Bates HK, Rush RE, Oller AR. Oral carcinogenicity study with nickel sulfatehexahydrate in Fischer 344 rats. Toxicol Appl Pharmacol 2007;224:126-37. doi: 10.1016/j. taap.2007.06.024

10. Chen CY, Lin TK, Chang YC, Wang YF, Shyu HW, Lin KH, Chou MC. Nickel(II)-induced oxidative stress, apoptosis, $\mathrm{G} 2 / \mathrm{M}$ arrest, and genotoxicity in normal rat kidney cells. J Toxicol Environ Health A 2010;73:529-39. doi: 10.1080/15287390903421250

11. Wang YF, Shyu HW, Chang YC, Tseng WC, Huang YL, Lin KH, Chou MC, Liu HL, Chen CY. Nickel (II)-induced cytotoxicity and apoptosis in human proximal tubule cells through a ROS- and mitochondria-mediated pathway. Toxicol Appl Pharmacol 2012;259:177-86. doi: 10.1016/j.taap.2011. 12.022

12. Chakrabarti SK, Bai C. Role of oxidative stress in nickel chloride-induced cell injury in rat renal cortical slices. BiochemPharmacol 1999;58:1501-10. doi: 10.1016/S00062952(99)00232-4

13. Valko M, Leibfritz D, Moncol J, Cronin MT, Mazur M, Telser J. Free radicals and antioxidants in normal physiological functions and human disease. Int J Biochem Cell Biol 2007;39:44-84. doi: 10.1016/j.biocel.2006.07.001

14. Ariharan VN, Kalirajan K, Meena Devi VN, Prasad NP. An exotic fruit which forms the new natural source for vitamin-C. Rasayan J Chem 2012;5:356-9.

15. Cathcart RF. Vitamin C: the nontoxic, nonrate-limited, antioxidant free radical scavenger. Med Hypotheses 1985;18:61-77. doi: 10.1016/0306-9877(85)90121-5

16. Guaiquil VH, Vera JC, Golde DW. Mechanism of vitamin C inhibition of cell death induced by oxidative stress in glutathione-depleted (HL60) cells. J BiolChem 2001;276:40955-61. doi: 10.1074/jbc.M106878200

17. Guo X, Lu J, Wang Y, Gui Y, Duan X, Cai Z. Ascorbate antagonizes nickel ion to regulate JMJD1A expression in kidney cancer cells. Acta Biochim Biophys Sin (Shanghai) 2012;44:330-8. doi: 10.1093/abbs/gms004

18. Das KK, Das SN. Studies on the role of ascorbic acid on nickel induced hepatic nucleic acid concentrations in rats. J Basic Clin Physiol Pharmacol 2004;14:185-95. doi: 10.1515/ JBCPP.2004.15.3-4.185

19. Gupta AD, Patil AM, Ambekar JG, Das SN, Dhundasi SA, Das KK. L-ascorbic acid protects the antioxidant defense system in nickel-exposed albino rat lung tissue. J Basic Clin Physiol Pharmacol 2006;17:87-100. doi: 10.1515/JBCPP. 2006.17.2.87

20. Ajith TA, Abhishek G, Roshny D, Sudheesh NP. Cosupplementation of single and multi doses of vitamins $\mathrm{C}$ and $\mathrm{E}$ ameliorates cisplatin-induced acute renal failure in mice. Exp Toxicol Pathol 2009;61:565-71. doi: 10.1016/j. etp.2008.12.002

21. Karabulut-Bulan O, Bolkent S, Yanardag R, Bilgin-Sokmen B. The role of vitamin $C$, vitamin $E$, and selenium on cadmium-induced renal toxicity of rats. Drug Chem Toxicol 2008;31:413-26. doi: 10.1080/01480540802383200 
22. Shaban El-Neweshy M, Said El-Sayed Y. Influence of vitamin C supplementation on lead-induced histopathological alterations in male rats. Exp Toxicol Pathol 2011;63:221-7. doi: 10.1016/j.etp.2009.12.003

23. Dhir H, Agarwal K, Sharma A, Talukder G. Modifying role of Phyllanthus emblica and ascorbic acid against nickel clastogenicity in mice. Cancer Lett 1991;59:9-18. PMID: 1878862

24. Chen CY, Huang YL, Lin TH. Effects of vitamin A pretreatment on nickel-induced lipid peroxidation and concentration of essential metals in liver, kidney and lung of mice. Arch Toxicol 1998;72:381-6. doi: 10.1007/ s002040050517

25. Horak E, Sunderman FW Jr. Nephrotoxicity of nickel carbonyl in rats. Ann Clin Lab Sci 1980;10:425-31. PMID: 7425533

26. Vyskocil A, Viau C, Cízková M. Chronic nephrotoxicity of soluble nickel in rats. Hum Exp Toxicol 1994;13:689-93. PMID: 7826687

27. Nabavi SF, Nabavi SM, Moghaddam AH, Naqinezhad A, Bigdellou R, Mohammadzadeh S. Protective effects of Allium paradoxum against gentamicin-induced nephrotoxicity in mice. Food Funct 2012;3:28-9. doi: 10.1039/c1 fo10173k

28. Sultana S, Verma K, Khan R. Nephroprotective efficacy of chrysin against cisplatin-induced toxicity via attenuation of oxidative stress. J Pharm Pharmacol 2012;64:872-81. doi: 10.1111/j.2042-7158.2012.01470.x

29. Novelli ELB, Hernandes RT, Novelli Filho JL VB, Barbosa LL. Differential/combined effect of water contamination with cadmium and nickel on tissues of rats. Environ Pollut 1998;103:295-300. doi: 10.1016/S0269-7491(98)00109-2

30. Amudha K, Pari L. Beneficial role of naringin, a flavanoid on nickel induced nephrotoxicity in rats. Chem Biol Interact 2011;193:57-64. doi: 10.1016/j.cbi.2011.05.003

31. Chatterjee K, Chakarborty D, Majumdar K, Bhattacharyya A, Chatterjee GC. Biochemical studies on nickel toxicity in weanling rats - influence of vitamin $\mathrm{C}$ supplementation. Int J Vitam Nutr Res 1979;49:264-75. PMID: 231018

32. Das KK, Buchner V. Effect of nickel exposure on peripheral tissues: role of oxidative stress in toxicity and possible protection by ascorbic acid. Rev Environ Health 2007;22: 157-73. doi: 10.1515/REVEH.2007.22.2.157

33. Fatima S, Arivarasu NA, Mahmood R. Vitamin C attenuates cisplatin-induced alterations in renal brush border membrane enzymes and phosphate transport. Hum Exp Toxicol 2007;26:419-26. PMID: 17623766

34. Solomons NW, Fernando V, Shuler TR, Nielsen FH. Bioavailability of nickel in man: effects of foods and chemically defined dietary constituents on the absorption of inorganic nickel. J Nutr 1982;112:39-50. PMID: 6798174

\section{Prethodna terapija vitaminom C štiti od niklom izazvane nefrotoksičnosti u miševa}

Nikal je sveprisutan kancerogeni i nefrotoksični metal čije djelovanje dovodi do oštećenja bubrežne funkcije. Rezultati prethodnih istraživanja dokazali su zaštitni učinak istodobne terapije vitaminom C na akutnu i kroničnu toksičnost izazvanu niklom. Međutim, vrlo je malo istraživanja o učinku prethodne terapije vitaminom C radi sprječavanja niklom izazvane akutne nefrotoksičnosti. Stoga se ovim ispitivanjem nastojala utvrditi učinkovitost prethodne terapije vitaminom C (VC) u sprječavanju akutne bubrežne toksičnosti izazvane niklom. Prije intraperitonealnog (IP) ubrizgavanja različitih doza

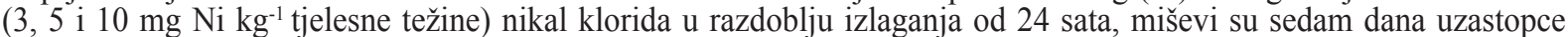
dobivali oralnu terapiju vitaminom $C\left(16,6 \mathrm{mg} \mathrm{kg}^{-1}\right.$ tjelesne težine). Nakon toga životinje su usmrćene, a bubrežno tkivo i uzorci krvi uzeti su radi histološke obrade i analize biokemijskih markera. U miševa koji su dobivali samo terapiju vitaminom C, serumske razine bubrežnih markera (kreatinin, urea i mokraćna kiselina) nisu bile promijenjene. Međutim, tretiranje samo niklom dovelo je do značajnog povećanja razina kreatinina, ureje i mokraćne kiseline te do značajnog broja nekrotičnih epitelnih stanica i infiltracije upalnih stanica u presjecima bubrega u usporedbi s kontrolnom skupinom. Prethodna terapija vitaminom C i tretiranje niklom u svim navedenim dozama tijekom 24 sata doveli su do značajnog smanjenja razina kreatinina, ureje i mokraćne kiseline u serumu te do poboljšanja histoloških promjena u usporedbi sa skupinom koja je tretirana samo niklom. Zaključuje se da prethodna terapija vitaminom C učinkovito poboljšava bubrežnu funkciju i oštećenje tkiva uzrokovano niklom. 